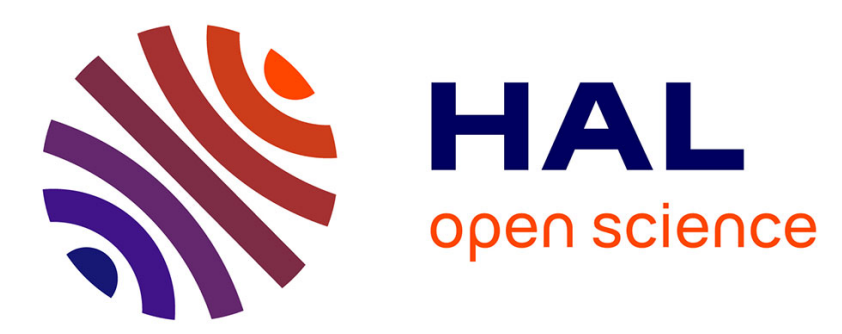

\title{
STUDY OF CHEMICAL COMPOSITION AND ELECTRONIC STRUCTURE OF HIGH-MELTING COMPOUNDS OF ZIRCONIUM BY ELECTRONIC AES
}

I. Brytov, A. Wander, V. Neshpor

\section{To cite this version:}

I. Brytov, A. Wander, V. Neshpor. STUDY OF CHEMICAL COMPOSITION AND ELECTRONIC STRUCTURE OF HIGH-MELTING COMPOUNDS OF ZIRCONIUM BY ELECTRONIC AES. Journal de Physique Colloques, 1984, 45 (C2), pp.C2-353-C2-356. 10.1051/jphyscol:1984280 . jpa00223994

\section{HAL Id: jpa-00223994 https://hal.science/jpa-00223994}

Submitted on 1 Jan 1984

HAL is a multi-disciplinary open access archive for the deposit and dissemination of scientific research documents, whether they are published or not. The documents may come from teaching and research institutions in France or abroad, or from public or private research centers.
L'archive ouverte pluridisciplinaire HAL, est destinée au dépôt et à la diffusion de documents scientifiques de niveau recherche, publiés ou non, émanant des établissements d'enseignement et de recherche français ou étrangers, des laboratoires publics ou privés. 
I.A. Brytov, A.S. Wander and V.S. Neshpor

VNIINauchprybor, Leningrad, U.S.S.R.

Résumë - Les changements de composition et de structure électronique des couches superficielles de carbures $Z_{r C}$ et des nitrures $2 r N_{y}$ dans les domaines d'existence $(0,51<\mathrm{x} \leqslant 1,0$, $0,76 \leqslant y \leqslant 1,07$, produits par chauffage sous bombardement électronique dans une gamme de températures de $300 \mathrm{~K} \leqslant \mathrm{~T}_{\mathrm{h}} \leqslant 2300 \mathrm{~K}$ sont étudiés par spectrométrie d'électrons Auger.

Abstract - Changes in chemical composition and electronic structure of surface layers of $\mathrm{ZrC}_{X}$ and $\mathrm{ZrNy}$ in areas of homogeneity $(0.51<x \leqslant 1.0,0.76 \leqslant y \leqslant 1.0)$ under the action of sample heating by electron bombardment within the temperature range $300 \mathrm{~K} \leqslant T_{\mathrm{h}} \leqslant 2300 \mathrm{~K}$ have been studied using layer-bylayer analysis of sample surface by AES.

Ti11 now study of zirconium nitrides and carbides have been performed in the main using $X$-ray methods which do not permit to obtain information about composition and electronic structure of surface layers of these materials. Not numerous papers on investigation of zirconium carbide using AES /1,2/ gave authors the possibility to carry out semiquantitative analysis of surface elemental composition of stoichiometric $\mathrm{ZrC}$ and its change in the course of interaction with oxygen and oxygen-bearing gases. Information obtained from nondifferentiated Auger-spectra may be used only indirectly for analysis; of chemical state of surface atoms because these spectra are low sensitive to the change of fine structure of Auger-lines comprising valence band. There are available very few papers on study of non-stoichiometric carbides and nitrides of $\mathrm{zr}$ using AES.

We performed analysis of samples of carbide $\mathrm{ZrC}_{x}$ and nitride $\mathrm{ZrN}$ in areas of homogeneity $(0.51<x \leqslant 1.0$ and $0.76 \leqslant y \leqslant 1.0)$ using AES method in a mode of differentiated Auger-spectra within the temperature range from 300 up to $2300 \mathrm{~K}$ when heating samples by electron bombardment in a vacuum of $10^{-9}$ torr.

Analysis of samples was performed for lines of MNN-series of $\mathrm{Zr}$ and KII-series of $\mathrm{C}, \mathrm{N}$ and $\mathrm{O}$. Fig. 1 shows Auger-spectra of polycrystalline stoichiometric samples of $\mathrm{Zr}_{1} .0$ and $\mathrm{ZrN}_{1.0}$ cleaned with heating up to $T_{h}=2300 \mathrm{~K}$ (curves 1 and 4 ) as well as spectra of these samples which were after cleaning during $13 \mathrm{hrs}$ in a vacuum chamber under the pressure of residual gases $p=10-5$ torr (curves 2 and 5 ). Curve 3 corresponds to $2 \mathrm{rC}_{1} .0$ sample heated up to $\mathrm{T}_{\mathrm{h}}=1100 \mathrm{~K}$ at $\mathrm{p}=10^{-5}$ torr. $\mathrm{M}_{5} \mathrm{~N}_{23} \mathrm{~N}_{45}-$ ine which is a single line in pure metallic $\mathrm{Zr}$ is splitted in both compounds into two lines, splitting value $\Delta E_{45}$ being $3 \mathrm{eV}$ 
for carbide and $5 \mathrm{eV}$ for nitride. Surfaces of $\mathrm{ZrC}$ and $\mathrm{ZrN}$ after interaction with residual gases gave similar spectra (curves 3 and 5 ) differing from spectra of pure samples by even larger splitting value

$\Delta E_{45}=7 \mathrm{eV}$.

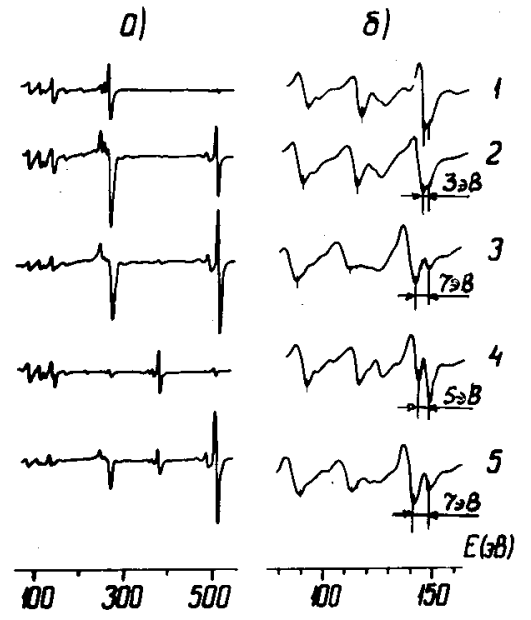

Fig。 1 - Auger-spectra of $2 \mathrm{rC} \times 0$ and $\mathrm{ZrN} 1,0 \cdot 1,4$ correspond to $\mathrm{ZrC}_{10}$ and $2 x \mathbb{N}_{1,0}$, respectively after heating up to $1000 \mathrm{~K}$ and the following fon bombardment; 2,5 correspond to $\mathrm{ZrC}, 10$ and $\mathrm{ZrN}$, o after 13 hrs of stay at $\mathrm{p}=10$-5torr; 3 corresponds to $\mathrm{ZrC} 10$ after heating up to $\mathrm{Th}=1100 \mathrm{~K}$ at $\mathrm{p}=$ 10-5 torr during $10 \mathrm{~min}$.

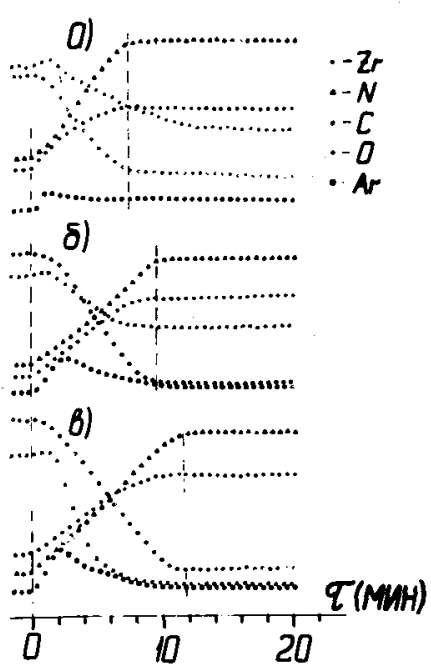

Fig. 4 - Profiles of Auger-line intensities distribution in depth of $Z$ riv samples, a) $Y=1.0 ; \delta$ ) $Y=$ 0.85 ; \&) $Y=0.76$. The following lines are taken for the elements: $\mathrm{Zx}-92 \mathrm{eV}, \mathrm{Ar}-215 \mathrm{eV}, \mathrm{C}-272 \mathrm{eV}$, $\mathrm{N}-381 \mathrm{eV}, 0-509 \mathrm{eV}$.

There is also observed difference in energetic position of other lines of MNN-series of $\mathrm{Zr}$ and shift towards the lower kinetic energies of electrons is increased with the increase of electronegativity of metalloid atoms in $\operatorname{ZrX}_{y}(X=C, N, 0)$. In samples of non-stoichiometric carbides and nitrides a value of $\Delta \mathrm{E}_{45}$ does not change in practice with the change of concentration of metalloid structural vacancies in crystal lattice. At the same time the redistribution of peak intensities in metal doublet takes place. In Fig. 2 there are shown spectra of $\mathrm{ZrC}_{\mathrm{x}}$ samples with the surface cleaned by ion bombardment. Nearing the lower boundary of the homogeneity area of carbide a height of long-wave peak is reduced as compared with a height of short-wave one. The situation is similar for $2 r N_{y}$ samples.

Note, that $\mathrm{KI}_{1} \mathrm{I}_{23}$-line of metelloid in compounds under study is also splitted and splitting value is close to a value of $\Delta \mathrm{E}_{45}$ in corresponding $\mathrm{M}_{5} \mathrm{~N}_{23} \mathrm{~N}_{45}$ - spectrum of $\mathrm{Zr}$.

Successive heating of samples from room temperature up to $2300 \mathrm{~K}$ shows that after cleaning the surface from contaminations and oxygen ( at $\mathrm{T}_{\mathrm{h}}=1200 \mathrm{~K}$ for $\mathrm{ZrN} \mathrm{Y}$ and $1600 \mathrm{~K}$ for $\mathrm{ZrC}_{\mathrm{X}}$ ) there are no changes 
of energetic position of spectrum lines. There is observed, however, a change in shape of MDN-series lines of Zr as well as a change of relation between line intensities connected with the loss of metalloid atoms in surface layers. In Fig. 3 there are shown Auger-spectra of $\mathrm{ZrC}_{\mathrm{x}}$ heated up to $\mathrm{T}_{\mathrm{h}}=1800 \mathrm{~K}$. Comparing Fig. 2 and Fig. 3 one can see a change of relation between short- and long-wave peaks after the heating and this change is the highest for $\mathrm{ZrC}_{0.6}$ sample.

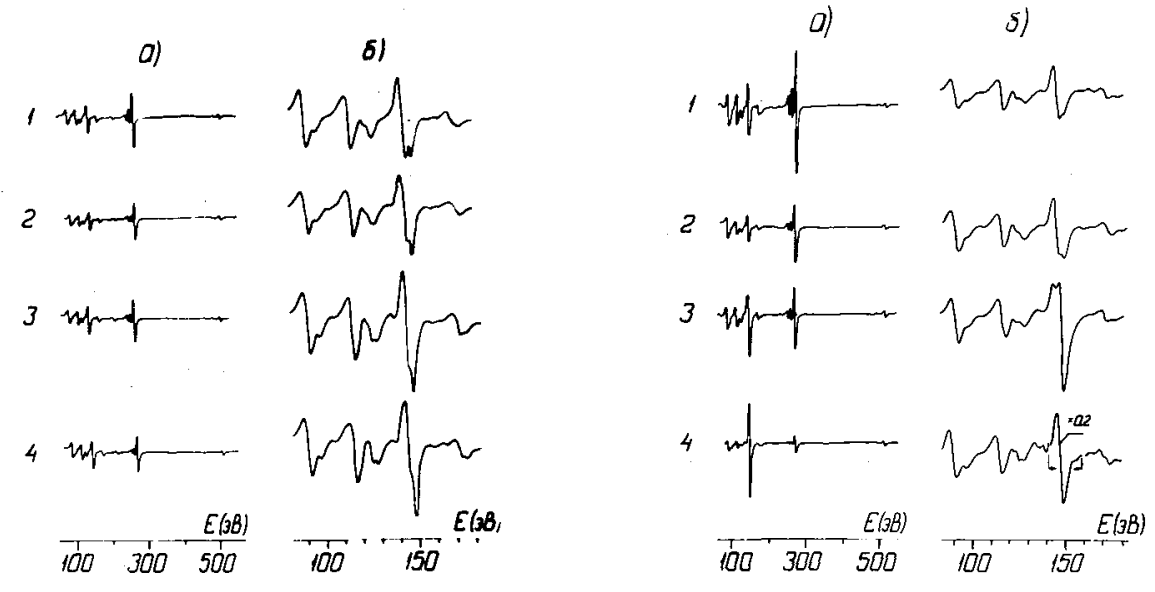

Fig. 2 - Spectra of $\mathrm{ZrCX}_{\mathrm{X}}$ samples Fig。 3 - Spectra of $\mathrm{ZrC}_{\mathrm{X}}$ samples subjected to ionic bombardment.

$1-X=1.0,2-X=0.8,3-X=0.7,1-X=1.0,2-X=0.8,3-X=0.7$ $4-X=0.6$; a) - survey spectra, $4-X=0.6$; a) - survey spectra, $\delta$ ) s) - MNN-series of $\mathrm{Zr}$. MNN-series of $\mathrm{Zr}$.

Layer-by-layer analysis of $\mathrm{ZrX}$ samples shows that the area of changed composition (relative to the volume one) near the surface is of $50 \mathrm{~A}$ and it is the wider the more is the concentration of metalloid vacancies in a sample volume. For nitride this area is approximately twice as wide as for carbide. As illustration in Fig. 4 there are shown intensity profiles of Auger-lines of $2 x N_{y}$ samples of various composition. Distribution profiles of 0 , Ar and $\mathrm{Zr}$ for $\mathrm{ZrC}_{\mathrm{x}}$ samples change in a similar way. Behaviour of distribution profile of the main metalloid in $Z r X y$ samples is identical.

The splitting of $\mathrm{M}_{5} \mathrm{~N}_{23} \mathrm{~N}_{45}$ - line of $\mathrm{Zr}$ in compounds under study is apparently connected with the splitting of d-band of $\mathrm{Zr}$ in states with the different symmetry of wave functions which according to calculation data $/ 3 /$ should be observed in analyzed metal-like compounds. At the same time according to calculation data for stoichiometric $\mathrm{ZrC}_{1.0}$ and $\mathrm{ZrN}_{1.0}$ the densities of $\mathrm{d}_{\gamma}$-states in occupied part of valence band are considerably higher than densities of $d_{\mathcal{E}}$-states near Fermi level. There are always a lot of open bonds on a surface resulting in redistribution of densities of $d_{\gamma}-$ and $d_{\varepsilon}-$ states which may be a reason of equalization of Auger-peak heights of $\mathrm{M}_{5} \mathrm{~N}_{23} \mathrm{~N}_{45}$-doublet of $\mathrm{Zr}$ as compared with the expected from theory high difference of heights. 
The splitting of $\mathrm{KJ}_{1} \mathrm{I}_{23}$-Iine of non-metal is also in good agreement with data of know calculations /3/ where occupied $2 p$-states of nonmetal are splitted. Unvariability of doublet shape in KLI-spectrum of metalloid is apparently connected with unvariability of nearest environment of $X$ atoms by metal atoms (octahedron $\left\langle M{ }_{6} X\right.$ > is always completed).

Intensity decrease of Iong-wave peak connected with Me-Me interaction is bound up with transition of a part of $\mathrm{d}_{\gamma}$-electrons of metal to $d \varepsilon$-states in breaking of Me- $x$ bonds. Such an explanation for

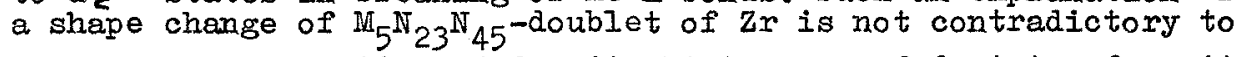
results of calculation of density histograms of d-states for nitride of isoelectronic analogue of $\mathrm{Zr}$ - TiN /4/. The calculation was performed taking into account non-completeness of $\mathrm{TiN}_{6}$ octahedron for nitrogen.

Known at present data on work function $P$ of cathodes of $2 r X y$ compounds are in good agreement with the data obtained in the present study on the surface composition change. So decrease of $\varphi$ with increase of temperature takes place due to the loss of metalloid atoms by a surface in case of non-congruent vaporization.

Thus the performed studies show that electronic Auger-spectra of surface contain valuable information about features of valence band structure in surface layers of analyzed compounds of $2 r X y$ type. The most interesting as we feel is the fact that the shape of Augerspectra comprising valence band may be used for evaluation of chemical bond type of surface atoms as well as for determination of metalloid concentration in homogeneous implantation phases of variable composition.

\section{References}

1. MATSKEVICH T.I., KAZANTSEV A.P., FTT 20 (1978) No. 113365.

2. MATSKEVICH T.I., KAZANTSEV A.P., Tezisy dokladov XVII vsesojuznoi konferentsii po emissionnoi electronike, Leningrad (1978) 203.

3. ZHURAKOVSKII E.A., Electronnaya structura tugoplavkikh soedinenif, Kiev, Naukova dumka (1976) 383

4. SHINJO K., OHNISHI S., TSUKADA M., SUGANO S., J. Phys. C: Solid State Phys. 14 (1981) 5575. 